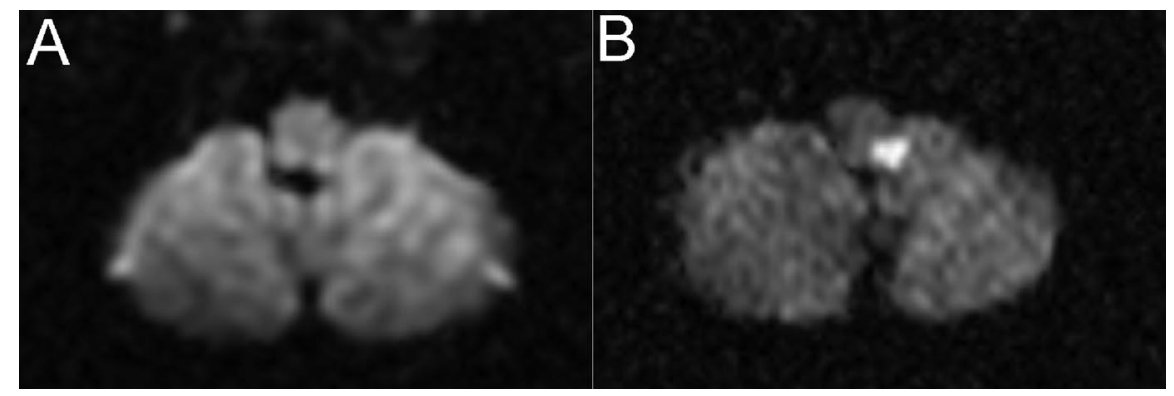

Figure. (A) Diffusion-weighted imaging performed on day 1 of symptoms shows no evidence of acute ischemia. (B) Repeat study performed 2 days later reveals a left lateral medullary infarction.

\title{
False-negative diffusion-weighted imaging with lateral medullary infarction
}

\author{
Rakesh Khatri, MD; James Leach, MD; and Matthew L. Flaherty, MD
}

A 55-year-old ${ }^{1}$ man awoke with left ear pain, vertigo, vomiting, left facial numbness, and ataxic gait. MRI including diffusionweighted imaging (DWI) performed 2 hours later showed no evidence of acute infarction (figure, A). Repeat MRI 2 days later showed DWI and FLAIR changes consistent with a left lateral medullary infarction (figure, B).
False-negative DWI has been reported in $5 \%$ of ischemic stroke cases, most commonly brainstem infarcts imaged within 24 hours of onset. Possible explanations include lesions too small for the resolution of the DWI echoplanar sequence, insufficient signal-tonoise ratio in the first hours after onset, and magnetic susceptibility artifacts causing image distortions. ${ }^{1}$ The clinical history and examination remain fundamental aspects of patient assessment in the era of advanced neuroimaging.

\section{Reference}

1. Oppenheim C, Stanescu R, Dormont D, et al. False-negative diffusion-weighted MR findings in acute ischemic stroke. AJNR Am J Neuroradiol 2000;21:1434-1440. 


\title{
Neurology
}

\author{
False-negative diffusion-weighted imaging with lateral medullary infarction \\ Rakesh Khatri, James Leach and Matthew L. Flaherty \\ Neurology 2006;67;E19 \\ DOI 10.1212/01.wnl.0000244494.50684.5b
}

This information is current as of November 27, 2006

\begin{abstract}
Updated Information \& Services

References

Subspecialty Collections

Permissions \& Licensing

Reprints

including high resolution figures, can be found at: http://n.neurology.org/content/67/10/E19.full

This article cites 1 articles, 1 of which you can access for free at: http://n.neurology.org/content/67/10/E19.full\#ref-list-1

This article, along with others on similar topics, appears in the following collection(s):

All Cerebrovascular disease/Stroke

http://n.neurology.org/cgi/collection/all_cerebrovascular_disease_strok e

\section{DWI}

http://n.neurology.org/cgi/collection/dwi

Infarction

http://n.neurology.org/cgi/collection/infarction

MRI

http://n.neurology.org/cgi/collection/mri

Information about reproducing this article in parts (figures,tables) or in its entirety can be found online at:

http://www.neurology.org/about/about_the_journal\#permissions

Information about ordering reprints can be found online:

http://n.neurology.org/subscribers/advertise
\end{abstract}

Neurology ${ }^{\circledR}$ is the official journal of the American Academy of Neurology. Published continuously since 1951, it is now a weekly with 48 issues per year. Copyright. All rights reserved. Print ISSN: 0028-3878. Online ISSN: 1526-632X.

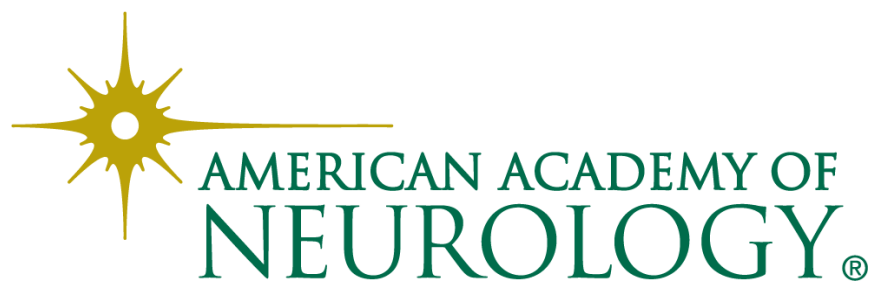

